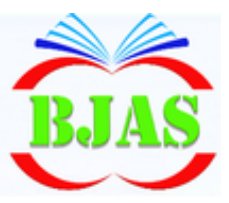

Available online at http://www.bajas.edu.iq

College of Agriculture, University of Basrah

DOi:10.21276/basjas

ISSN 1814 - 5868 Basrah J. Agric. Sci., 32(Spec Issue): 266-275, 2019

\section{Basrah}

Journal of

Agricultural

Sciences

E-ISSN: 2520-0860

\title{
Insecticidal activity of Spinosad and Emamectin and Their Mixture with Different Types of Inert Dusts against Khabra Larvae Trogoderma granarium Everts
}

\author{
Nabil M. Almallah* \& Ahmed M. Jihad \\ Department of Plant Protection, College of Agriculture, University of Mosul, Iraq \\ *corresponding author: nbl_mstf@yahoo.com
}

Received 4 May 2019; Accepted 2 September 2019; Available online 10 October 2019

\begin{abstract}
The study showed that the highest activation percentage of the insecticides (Spinosad, Emamectin and the mixture of the insecticides) were obtained when mixed with silica gel for the larvae grown on the corn (2.266, 1.255 and 1300 respectively), while the lowest activation percentage (Antagonism) was recorded for the mixture of each of the Spinosad and Emamectin separately with the gypsum of the larvae grown on the wheat giving 0.776 and 0.989 , respectively. The highest of synergism percentage was for silica gel when mixed with each of Spinosad, Emamectin and the mixture of insecticide against the larvae which grown on corn reached 2.014, 1.178 and 1.256 respectively; the lowest of synergism percentage was for gypsum when mixed with the Spinosad and the insecticide mixture against larvae grown on the wheat, which reached 0.454 and 0.918 respectively, while the ratio was 0.841 for the Emamectin insecticide when mixed with the limestone against the larvae which grown on wheat. For the percentage of potentiation, the study showed that the treatment of larvae grown on wheat and corn which treated with a mixture (silica gel and Spinosad insecticide) gave the highest percentage of the potentiation of the pesticide reached 0.41 and 0.252 respectively, and the lowest potentiation percentage of larvae on wheat and maize was recorded for gypsum with the mixture of insecticides reaching 0.082 and 0.016 respectively.
\end{abstract}

Keywords: Activation, Emamectin, Inert dust, Khabra Larvae, Spinosad, Synergisim.

\section{Introduction}

Stored grain insects are one of the main causes of stored grain losses which may reach $9 \%$ in developed countries and 20\% or more in developing countries (Phillips \& Throne, 2010). Khabra beetle Trogoderma granarium Everts is one of the most important stored grain pests, the most dangerous and resistant to insecticides (Mahmood et al., 1996). It

adapts to various environmental conditions, where larvae can survive for 23 months without food and enter into dormancy until the food is available. Nowadays, Khabra beetle developed resistance to many insecticides, especially organophosphorus 
compounds (Arthur, 1996). The increased need for pesticide residues free food has led to the search for new and less dangerous techniques of control, including the use of inert dust, biocides or natural extracts from plants or microorganisms that have been evaluated as alternative techniques to the traditional chemical insecticides (Vayias et al., 2009). Spinosad and Emamectin are among the most important promising bioinsecticides that are derived from microorganisms, which have a new effect on specific sites in the nervous system of the insect that are the receptors of nicotinic acetylcholine, and the chemical carrier GABA (Gama Amino Butyric Acid) which found in the musculoskeletal regions of the nervous system (Salgado, 1997).

The Spinosad insecticide is a safe pesticide for the environment and public health that affects a wide range of pests, including stored product pests (Fang et al., 2002; Nayak et al., 2005); also it has low toxicity to mammals (Fang et al., 2002; Subramanyam et al., 2003). For these reasons, Spinosad was recommended by the US Environmental Protection Agency for the protection of stored grain in 2005 (Subramanyam, 2006). Another promising and alternative way to conventional chemical insecticides is the use of inert dust because of its low toxicity to mammals (Subramanyam \& Roesli, 2000). These materials are now well known to be scratching the fatty layer which found in the insect's cuticle. Many of these materials are commercially available for use in the protection of stored food and many have proved to be very effective in both field and laboratory tests (Athanassiou et al., 2003; 2004; 2005; Kavallieratos et al., 2005). On the other hand, the use of inert dusts has a negative effect on the physical properties of grains, especially the bulk density (Korunic et al., 1998). The effectiveness of these substances in the protection of stored food requires high concentrations or doses more than 500 ppm (Vayias et al., 2006); this problem is the main constraint in the use of these substances. Also the bio-insecticides are characterized by their slow action compared to conventional chemical insecticides. The present study aimed at overcoming the negative effects or problems resulting from the use of inert dusts or bio-insecticides separately by combining them.

\section{Materials \& Methods}

\section{Source of Insects and Rearing}

Trogoderma granarium Everts was obtained from an insect culture previously raised in the insect research laboratory of the Department of Plant Protection, Faculty of Agriculture and Forestry, University of Mosul. The insect was reared on healthy and cleaned wheat grain Aestivum triticum L. on incubator at $30 \pm 1^{\circ} \mathrm{C}$ and $60 \pm 5 \%$ relative humidity in $1 \mathrm{~kg}$ plastic cans. Its nozzle was covered with malleable cloth and sealed with rubber bands. The culture was cleaned from time to time to get rid of the moulting skin. The culture was renewed after each generation by taking the new insects out of the pupa stage to work for other cultures.

\section{Bio-insecticides}

\section{Spinosad pesticide}

inseticide equipped with a Suspension Concentrate (SC) containing $480 \mathrm{~g}$ of Spinosad (active ingredient) per a litre of commercial formulation, the trade name of 
the inseticide is Tracer, produced by Dow Agrosciences (Copping \& Duke, 2007 ).

\section{Emamectin}

Emulsifiable concentrate containing $2 \%$ Emamectin benzoate (effective ingredient) per a litre of commercial formulation, the brand name is EMAVAP produced by Vapco.

\section{The materials used in the study}

\section{Silica gel:}

It is fine white powder which obtained from the Branch of Basic Sciences, Faculty of Agriculture and Forestry, University of Mosul. Its chemical composition is H2F2S4 type 60 .

\section{Limestone Powder}

It is a natural calcium carbonate deposit $\left(\mathrm{CaCO}_{3}\right)$ in the form of calcite metal forming rocks known as limestone. It may be white or grey. which obtained from the Department of Earth Sciences at the Faculty of Science, University of Mosul.

\section{Gypsum powder}

It is a calcium sulphate dihydrate (CaSO4.2H2O) which is deposited naturally as rocks known as gypsum rocks. It was obtained from the Department of Earth Sciences, Faculty of Science, University of Mosul.

\section{Laboratory experiments}

All experiments were carried out in the Insect Research Laboratory, Department of Plant Protection during 2013-2014.

\section{1- Effect of acute toxicity values (LC50) of insecticides and inert dust against larvae of Khabra beetle.}

Five concentrations of 500, 1000, 1500, 2000 and $2500 \mathrm{ppm}$ were used for the commercial formulation of spinosad and 250, 500, 750, 1000 and $1500 \mathrm{ppm}$ of Emamactin were prepared to test on the third instar larvae with three replicates for each concentration. Each replicate included ten larvae which were placed in a Petri dish after treating with immersion method for two seconds with the above concentrations of each insecticide and $10 \mathrm{~g}$ of wheat grains were added to each replicator (the food host on which the insect was fed). The dishes were placed under laboratory conditions at an average temperature of $25 \pm 5^{\circ} \mathrm{C}$ and relative humidity $60 \pm 5 \%$. The treatment of the control experiment was treated with water only, and the mortality rate was calculated after 24 and 48 hours of treatment. The experiments of the insecticide mixture were done in the same way after mixing the insecticides with 1: 1 and using five concentrations of 250, 500, 750, 1000 and 1500 ppm.

The values of LC50 for inert powders were calculated by exposing the larvae of the third instar to four concentrations of inert dusts (silica gel, limestone and gypsum) as follows (10, 30, 50 and 70) $\mathrm{g}$. $\mathrm{kg}^{-1}$ grains. $10 \mathrm{~g}$ of wheat grains were placed with each concentration of inert dusts concentrations the treated material was placed in plastic containers of $50 \mathrm{ml}$ and covered with a tapestry cloth and tied with a rubber band with three replicates per concentration. Ten larvae were transferred to each replicate of the experiment. Treatment of the control experiment was left without the addition of the inert dusts. The containers are placed under laboratory conditions at an average temperature of 25 $\pm 5^{\circ} \mathrm{C}$. The humidity of the grain used in the 
study was stabilized to no more than $14 \%$ using the HOH-EXPRESS.HE50 grain moisture meter and the death ratio was corrected using the Abbott (1925) equation. The LC50 values for each insecticide were calculated using Finney (1971), mentioned in Al-Mallah \& Al-Jubouri (2012).

2- Effect of the values of the active components of inert powders with insecticides against the larvae of the Khabra beetle grown on the wheat and corn seeds

Ten grams of each food host (wheat and corn) was treated with LC10, LC25 and LC50 concentrations of Spinosad and Emamectin separately and their mixed which calculated from the first axis of the study by dipping for one minute with three replicates per treatment. The treated food was then placed on filter paper then transferred to plastic cans, ten third instar larvae were transferred to each replicate.
The cans were covered with mesh cloth and fixed with a rubber band. All treatments were tested under laboratory conditions at an average temperature of $25 \pm 5{ }^{\circ} \mathrm{C}$ and relative humidity $30 \pm 5 \%$, the control treatment was treated only water.

The above-mentioned experiment was repeated for the three inert powders (silica gel, limestone, gypsum); the treated and non-treated wheat and corn grains with Spinosad and Emamectin individually and mixture were treated with LC10, LC25 and LC50 concentrations). Then all these treatments were treated with LC50 concentration for each of the three powders. The data of mortality rates after 1,3 , and 7 days of the treatment was calculated, as the ratio of synergy and activation of the abovementioned transactions using the following equations mentioned in the Al-Mallah \& Al- Jubouri (2012).

First: calculation of the total activation ratios: according to the Metcalf's equation:

$$
\text { Total Activation Rate }=\frac{\text { LC50 value of the pesticide }}{\text { LC50 value of the mixture }}
$$

Second: Calculation of the synergy ratio: Excluding the potentiation ratio, which represents the percentage of killing caused by the activated substance in the test animals. This method can be summarized in the following steps:

a. Find the corrected mortality ratios for both insecticides and inert dusts concentrations. b. Find the corrected mortality ratios for insecticides and inert dust mixtures concentrations.

c. Correct the mortality ratio of the mixture using the Abbott equation mentioned in the Al-Mallah \& Al- Jubouri (2012)

$$
\begin{gathered}
\% \text { corrected kill for the mixture }= \\
\frac{\% \text { Kill for the mixture }-\% \text { kill the activated substance }}{100-\% \text { Kill the activated substance }} * 100
\end{gathered}
$$

d. Determine LC50 values for both insecticide and mixture 
e. Calculation of the synergistic effect ratio using Metcalf's equation:

$$
\text { Percentage of synergistic effect }=\frac{\text { LC50 value of the pesticide }}{\text { LC50 value for the corrected mixture }}
$$

Third: Calculation of the potentiation ratio in activated substances: by using the following equation:

Potentiation ratio $=$ Total activation ratio Synergy ratio

\section{Results \& Discussion}

Effect of food host species on the values of the activation constituents of the inert dusts with insecticides against the Khabra beetle larvae:

Table (1) shows that the activation ratios for mixtures of inert dust and insecticides varied according to the type of inert dust, the type of insecticide and the type of host. In general, it was found that when treated larvae reared on corn with a mixture (silica gel and spinosad) gave the highest rate of activation of the insecticide (2.266) and the lowest activation rate appeared when treated larvae reared on wheat with a mixture (gypsum and spinosad) reaching 0.776 (antagonist). It was also noted that the highest activation rate of the three insecticides (Spinosad, Emamectin and their mixture) were obtained when mixed with silica gel for larvae reared on corn at 2.266, 1.255 and 1300, respectively. While the lowest activation ratio was recorded for the mixture of both Spinosad and Emamectin separately with the gypsum of larvae reared on wheat, giving 0.776 and 0.989 respectively.

Table (1): Total activation ratio of silica gel, limestone and gypsum with both Spinosad, Emamectin and the insecticide mixture against the larvae of the Khabra beetle grown on wheat and corn.

\begin{tabular}{|c|l|c|c|c|c|c|c|}
\hline \multirow{2}{*}{$\begin{array}{c}\text { Type } \\
\text { of } \\
\text { food } \\
\text { host }\end{array}$} & $\begin{array}{c}\text { Type of } \\
\text { Inert dust } \\
\text { additive }\end{array}$ & \multicolumn{2}{|c|}{$\begin{array}{c}\text { LC50 value of insecticides and } \\
\text { their mixtures ppm }\end{array}$} & \multicolumn{3}{|c|}{ Total Activation Rate } \\
\cline { 3 - 8 } & Spinosad & Emamectin & $\begin{array}{c}\text { Their } \\
\text { mixture }\end{array}$ & Spinosad & Emamectin & $\begin{array}{c}\text { Their } \\
\text { mixture }\end{array}$ \\
\hline \multirow{4}{*}{ Wheat } & $\begin{array}{l}\text { Without } \\
\text { adding }\end{array}$ & 17.087 & 15.603 & 13.683 & - & - & - \\
\cline { 2 - 9 } & Silica Gel & 13.986 & 14.175 & 11.263 & 1.221 & 1.100 & 1.214 \\
\cline { 2 - 8 } & Limestone & 17.143 & 14.758 & 13.267 & 0.996 & 1.057 & 1.031 \\
\cline { 2 - 8 } & gypsum & 21.992 & 15.771 & 13.681 & 0.776 & 0.989 & 1 \\
\hline \multirow{5}{*}{ Corn } & $\begin{array}{l}\text { Without } \\
\text { adding }\end{array}$ & 34.727 & 22.756 & 18.955 & - & - & - \\
\cline { 2 - 8 } & Silica Gel & 17.241 & 19.305 & 15.080 & 2.266 & 1.255 & 1.300 \\
\cline { 2 - 8 } & Limestone & 21.499 & 23.293 & 17.813 & 1.790 & 1.051 & 1.109 \\
\cline { 2 - 8 } & Gypsum & 36.045 & 23.174 & 17.807 & 1.101 & 1.013 & 1.080 \\
\hline
\end{tabular}


This results were in agreement with Al-Mallah \& Al-Sabaa (2005) who showed that LC50 values for insect growth inhibitors (EC 50\% Match and EC 10\% Dimilin and WP 75\% Trigard) varied according to the type of food (date, figs) and the type of insect Ephestia cautella Walk. Ephestia calidella Guenee. Akbar et al. (2004) pointed out that the rustic flour beetle Tribolium castaneum did not respond to any of the concentrations used of Beauveria bassiana. and addition of diatomaceous earth (DE) powders did not significantly increase the mortality rate of these adults. While the use of DE against the larvae of this insect at concentration of 190 mg. $\mathrm{kg}^{-1}$ grains, had the activation effect which enhanced the effectiveness of the fungus $B$. bassiana and at all concentrations, ranging from $33-2700 \mathrm{mg}$ of the conidia. $\mathrm{kg}^{-1}$, The same authors confirmed that this ratio supported the hypothesis that the DE material enhanced the effect of $B$. bassiana against larvae $T$. castaneum especially in the affected part of insect cuticle.

Athanassiou \& Korunic (2007) found that inert dust which enhanced with abamectin (DEA-p /wp and bitterbarkomycin (DEBBM$\mathrm{p} / \mathrm{wp}$ ) were more effective against four of the stored beetles (Sitophilus oryzae, Ryzopertha dominica, Tribolium castaneum) as compared to preparations currently commercially available from DE .

Table (2) shows that the synergy ratio for the mixtures of insecticides and inert dust varied according to the type of food host to which the larvae were fed, the type of the inert dust and the insecticide.

Table (2): The synergistic effect of inert dusts (silica gel, limestone and gypsum) with both the Spinosad, Emamectin and the insecticide mixture against the larvae of the Khabra beetle grown on wheat and corn.

\begin{tabular}{|c|c|c|c|c|c|c|c|}
\hline \multirow{2}{*}{$\begin{array}{c}\text { Type of } \\
\text { food } \\
\text { host }\end{array}$} & $\begin{array}{c}\text { Type of Inert } \\
\text { dust additive }\end{array}$ & \multicolumn{2}{|c|}{$\begin{array}{c}\text { LC50 value of insecticides and } \\
\text { their mixtures after correction }\end{array}$} & \multicolumn{3}{|c|}{ Synergy rate } \\
\cline { 3 - 7 } & & Spinosad & Emamectin & $\begin{array}{c}\text { Their } \\
\text { mixture }\end{array}$ & $\begin{array}{c}\text { Spinosa } \\
\mathrm{d}\end{array}$ & Emamectin & $\begin{array}{c}\text { Their } \\
\text { mixture }\end{array}$ \\
\hline
\end{tabular}

\begin{tabular}{|c|l|c|c|c|c|c|c|}
\hline \multirow{5}{*}{ Wheat } & $\begin{array}{l}\text { Without } \\
\text { adding }\end{array}$ & 17.087 & 15.603 & 13.683 & - & - & - \\
\cline { 2 - 8 } & Silica Gel & 21.060 & 17.941 & 12.822 & 0.811 & 0.869 & 1.067 \\
\cline { 2 - 8 } & Limestone & 24.546 & 18.549 & 14.769 & 0.696 & 0.841 & 0.926 \\
\cline { 2 - 8 } & Gypsum & 37.605 & 17.935 & 14.905 & 0.454 & 0.869 & 0.918 \\
\hline \multirow{3}{*}{ Corn } & $\begin{array}{l}\text { Without } \\
\text { adding }\end{array}$ & 34.727 & 22.756 & 18.955 & - & - & - \\
\cline { 2 - 8 } & Silica Gel & 17.241 & 19.305 & 15.080 & 2.014 & 1.178 & 1.256 \\
\cline { 2 - 8 } & Limestone & 21.499 & 23.293 & 17.813 & 1.615 & 0.976 & 1.064 \\
\hline
\end{tabular}


Almallah \& Jihad . / Basrah J. Agric. Sci., 32 (Special Issue): 266-275, 2019

\begin{tabular}{|l|l|l|l|l|l|l|l|}
\hline & Gypsum & 36.045 & 23.174 & 17.807 & 0.963 & 0.981 & 1.064 \\
\hline
\end{tabular}

Table (3): Values of the activation components for each of the iner dusts (silica gel, limestone and gypsum) with the insecticides (Spinosad, Emamectin and the insecticides mixture) against the Khabra beetle larvae on wheat and corn.

\begin{tabular}{|c|c|c|c|}
\hline \multicolumn{4}{|c|}{ Wheat } \\
\hline The mixture & Total activation values & Synergy rate & Potentiation rate \\
\hline Spinosad + Silcagel & 1.221 & 0.811 & 0.41 \\
\hline Spinosad + Limestone & 0.996 & 0.696 & 0.3 \\
\hline Spinosad + Gypsum & 0.776 & 0.454 & 0.322 \\
\hline Emamectin + Silcagel & 1.100 & 0.869 & 0.231 \\
\hline Emamectin + Limestone & 1.057 & 0.841 & 0.216 \\
\hline Emamectin + Gypsum & 0.989 & 0.869 & 0.12 \\
\hline $\begin{array}{l}\text { Mixture of insecticides + } \\
\text { Silcagel }\end{array}$ & 1.214 & 1.067 & 0.147 \\
\hline $\begin{array}{l}\text { Mixture of insecticides }+ \\
\text { Limestone }\end{array}$ & 1.031 & 0.926 & 0.105 \\
\hline $\begin{array}{l}\text { Mixture of insecticides + } \\
\text { gypsum }\end{array}$ & 1 & 0.918 & 0.082 \\
\hline \multicolumn{4}{|c|}{ Corn } \\
\hline Spinosad + Silcagel & 2.266 & 2.014 & 0.252 \\
\hline Spinosad + Limestone & 1.790 & 1.615 & 0.175 \\
\hline Spinosad + Gypsum & 1.101 & 0.963 & 0.138 \\
\hline Emamectin + Silcagel & 1.255 & 1.178 & 0.077 \\
\hline Emamectin + Limestone & 1.051 & 0.976 & 0.075 \\
\hline Emamectin + Gypsum & 1.013 & 0.981 & 0.032 \\
\hline $\begin{array}{l}\text { Mixture of insecticides + } \\
\text { Silcagel }\end{array}$ & 1.300 & 1.256 & 0.044 \\
\hline $\begin{array}{l}\text { Mixture of insecticides }+ \\
\text { Limestone }\end{array}$ & 1.109 & 1.064 & 0.045 \\
\hline
\end{tabular}




\begin{tabular}{|l|l|l|l|}
\hline $\begin{array}{l}\text { Mixture of insecticides }+ \\
\text { gypsum }\end{array}$ & 1.080 & 1.064 & 0.016 \\
\hline
\end{tabular}

In general, the highest synergism was reached 2.014 for the silica gel and spinosad mixture with Khabra larvae feeding on corn, while the lowest synergism was obtained from larvae feeding on wheat which treated with gypsum and spinosad mixture (0.454).

The synergy ratio of silica gel with Emamectin and insecticide mixture were 1.178 and 1.256 respectively for larvae reared on corn. In a study of the synergistic effect of DE powders with the deltamethrin insecticide in the control of stored food insects and for the purpose of calculating the synergy by potentiation the mixture; Korunic \& Rozman (2010) reported the co-toxicity and Coefficiencies on studies insects which reached more than 100 (170-386) of Sitophilus zeamais, (188-601) for Ryzopertha dominica and T. castaneum (157-285), which clearly indicate the synergistic effect of DE and deltamethrin.

Finally, it was found from the table (3) that the highest potentiation was from the silica gel and Spinosad mixture as it reached 0.41 ,

0.252 for larvae reared on wheat and corn respectively. While the lowest potentiation percentage was for the gypsum and insecticide mixture which reached $0.082,0.016$ for larvae reared on wheat and corn respectively. Chintzoglou et al. (2008) demonstrated the possibility of combined use of spinosad powder with DE but the effectiveness of this usage differed according to the target insect and the type of treated grains.

Vayias et al. (2009) indicated that low doses of DE (less than $600 \mathrm{ppm}$ ) with spinosad (less than $1 \mathrm{ppm})$ to control the adults, larvae of Tribolium confusum especially at a temperature greater than $25{ }^{\circ} \mathrm{C}$. The results of the Wakil et al. (2013) on the effect of grain type showed an increase in the death rates for the insects fed to the treated wheat compared to rice or corn.

\section{Conclusion}

The type of food host (wheat, corn) used in insect rearing, the type of inert dust and the insecticide had played an important role for Khabra larvae response to insecticides and their mixture with inert dusts which is reflected on the values of total activation and ratios of synergy and potentiation. The highest activation and synergy of insecticides were achieved when mixed with the silica gel for the larvae reared on the corn, while the lowest activation rate (antagonist) was recorded at mix it with gypsum and for larvae reared on wheat.

\section{Acknowledgments}

Our thanks and appreciation to staff of the Department of Plant Protection, Faculty of Agriculture and Forestry, University of Mosul for its cooperation in completing the requirements of this work.

Conflict of interest: The authors declare that they have no conflict of interest.

Ethical approval: all applicable national and international guidelines for the care and use of animals were followed.

\section{References:}


Abbott, W.B. (1925). A method of computing the effectiveness of an insecticide. J. Econ. Entomol., 18: 265-267.

Akbar, W.; Lord, J.C.; Nechols, J.R. \& Howard, R.W. (2004). Diatomaceous earth increases the efficacy of Beauveria bassiana against Tribolium castaneum larvae and increases conidia attachment. J. Econ. Entomol., 97(2): 273-280

Al-Mallah, N.M \& Al-Jubouri, A.R. (2012). Practical applications in pesticides. Dar Al Ola Publ., Mosul: 537pp.

Al-Mallah, N.M \& Al-Sabaa, R.R (2005). Effect of the type of food host and some of the growth inhibitors in the rate of loss of food and the rate of increase of fig leaf and raisins. Tikrit Col. Pure Sci., 10 (1): 25-29.

Arthur, F.H. (1996). Grain protectants: current status and prospects for the future J. Stored Prod. Res., 32: 293-302.

Athanassiou, C.G. \& Korunic, Z. (2007). Evaluation of two new diatomaceous earth formulations, enhanced with abamectin and bitterbarkomycin, against four stored-grain beetle species. J. Stored Prod. Res., 43 (4): 468-473.

Athanassiou, C.G.; Kavallieratos, N.G. \& Andris, N.S. (2004). Insecticidal effect of three diatomaceous earth formulations against adults of Sitophilus oryzae (Coleoptera: Curculionidae) and Tribolium confusum (Coleoptera: Tenebrionidae) on oat, rye and triticale. J. Econ. Entomol., 97: 2160-2167.

Athanassiou, C.G.; Kavallieratos, N.G.; Tsaganou, F.C.; Vayias, B.J.; Dimizas, C.B. \& Buchelos, C.Th. (2003). Effect of grain type on the insecticidal efficacy of SilicoSec against Sitophilus oryzae (L.) (Coleoptera: Curculionidae). Crop Prot., 22: 1141-1147.
Athanassiou, C.G.; Kavallieratos, N.G.; Economou, L.P.; Dimizas, C.B.; Vayias, B.J.; Tomanovic, S. \& Milutinovic, M. (2005). Persistence and efficacy of three diatomaceous earth formulations against Sitophilus oryzae (Coleoptera: Curculionidae) on wheat and barley. J Econ. Entomol., 98: 1404-1412.

Chintzoglou, G.; Athanassiou, C.G. \& Arthur, F.H. (2008). Insecticidal effect of spinosad dust, in combination with diatomaceous earth, against two stored-grain beetle species. J. Stored Prod. Res., 44: 347- 353.

Copping, L.G., \& Duke, S.O. (2007). Natural products that have been used commercially as crop protection agents. Pest Manag. Sci., 63(6): 524-554.

Fang, L.; Subramanyam, B. \& Arthur, F. H. (2002). Effectiveness of Spinosad on four classes of wheat against five stored product insects. J. Econ. Entomol., 95(3): 640-650.

Finney, D.J. (1971). Probit analysis. $3^{\text {rd }}$ ed. London, Cambridge Univ. Press: 333pp.

Kavallieratos, N.G.; Athanassiou, C.G.; Paschalidou, F.G.; Andris, N.S. \& Tomanovic, Z. (2005). Influence of grain type on the insecticidal efficacy of two diatomaceous earth formulations against Rhyzopertha dominica (F.) (Coleoptera: Bostrychidae). Pest Manag. Sci., 61: 660666.

Korunic, Z. (1998). Diatomaceous earths, a group of natural insecticides. J Stored Prod. Res., 34: 87-97.

Korunic, Z. \& Rozman, V. (2010). A synergistic mixture of diatomaceous earth and deltamethrin to control stored grain insects. 10th Int. Working Conf. on Stored Product Protection. 27 June to 2 July 2010, Estoril, Portugal. Julius Kühn-Institut, Berlin, Germany. 
Mahmood, T.; Ahed, M.S. \& Ahmeed, H. (1996). Dispersion of stored grain insect pests in a wheat fill Silo. Int. J. Pest Mang. 42: 321-324.

Nayak, M.K.; Daglish, G.J. \& Byrne, V.S. (2005). Effectiveness of spinosad as a grain protectant against resistant beetle and psocid pests of stored grain in Australia. J. Stored Prod. Res., 41: 455-467.

Phillips, T.W. \& Throne, J.E. (2010). Biorational approaches to managing Storedproduct insects. Anim. Rev. Entomol., 55: 375-397.

Salgado, V.L. (1997). The mode of action of spinosad and other insect control products. Down to Earth, 52(1): 35-43.

Subramanyam, Bh. \& Roesli, R. (2000). Inert dusts.. In: Subramanyam, B. \& Hagstrum, D.W. (Eds.). Alternatives to pesticides in stored-product IPM. Kluwer Academic Publishers, Dordreecht, pp.321-380.

Subramanyam, Bh., Toews, M.D. \& Fang, L., (2003). Spinosad: an effective replacement for organophosphate grain protectants. Pp. 916-920. In: Credland, P.F.; Armitage, D.M.; Bell, C.H.; Cogan, P.M. \& Highley, E. (Eds.). Proc. $8^{\text {th }}$ Int. Working Conf. on Stored-Product Protection, 22-26 July 2002, York. CAB Int., Wallingford, Oxon.

Subramanyam, Bh. (2006). Performance of spinosad as a stored grain protectant. Pp:
730-740. In: Lorini, I., Bacaltchuk, B., Beckel, H., Deckers, E., Sundfeld, E., dos Santos, J.P., Biagi, J.D., Celaro, J.C., Faroni, L.R.D'A., de Bortolini, L.O.F., Sartori, M.R., Elias, M.C., Guedes, R.N.C., da Fonseca, R.G., Scussel, V.M. (Eds.). Proc. $9^{\text {th }}$ Int. Working Conf. on StoredProduct Protection, 15-18 October 2006, Campinas. ABRAPOS, Rodovia.

Vayias, B.J.; Athanassiou, C.G.; Kavallieratos, N.G. \& Buchelos C.T (2006). Susceptibility of different European populations of Tribolium confusum (Coleoptera: Tenebrionidae) to five diatomaceous earth formulations. J. Econ. Entomol., 99: 18991904

Vayias, B.J.; Athanassiou, C.G. \& Buchelos, C.Th. (2009). Effectiveness of spinosad combined with diatomaceous earth against different European strains of Tribolium confusum du Val (Coleoptera: Tenebrionidae): Influence of commodity and temperature. J. Stored Prod. Res., 45: 165176.

Wakil, W.; Riasat, T. \& Lord, J.C. (2013). Effects of combined thiamethoxam and diatomaceous earth on mortality and progeny production of four Pakistani populations of Rhyzopertha dominica (Coleoptera: Bostrichidae) on wheat, rice and maize. J. Stored Prod. Res., 52. 28-35. 